\title{
Pyruvate Kinase PKM
}

National Cancer Institute

\section{Source}

National Cancer Institute. Pyruvate Kinase PKM. NCI Thesaurus. Code C74443.

Pyruvate kinase PKM (531 aa, $\sim 58 \mathrm{kDa}$ ) is encoded by the human PKM gene. This protein is involved in muscle cell glycolysis and may play a role in bacterial pathogenesis. 